\title{
Paweł STACHOWIAK
}

DOI 10.14746/ssp.2016.4.10

Uniwersytet im. Adama Mickiewicza w Poznaniu

\section{Nacjonalizm polski w optyce niemieckiej lat trzydziestych XX w.}

Streszczenie: Niemieckie zainteresowanie polskim nacjonalizmem było w latach trzydziestych niewielkie. Więcej miejsca i uwagi poświęcały mu jedynie czasopisma i wydawnictwa zajmujące się szczególnie problematyką wschodnioeuropejską. Niemal całkowicie pomijały oficjalne źródła NSDAP.

Problem relacji między polskim nacjonalizmem a faszyzmem i narodowym socjalizmem stał się przedmiotem refleksji naukowej. Niestety jak dotąd nie dokonano podobnej analizy biorąc jako punkt wyjścia Niemcy ówczesnej epoki. Warto zadać pytanie, czy również tam, w publicystyce, w publikacjach naukowych, rozwój polskiego nacjonalizmu wzbudzał zainteresowanie? Jak postrzegali swych polskich ideowych pobratymców zwolennicy ruchu nazistowskiego, jak odnosili się do nich publicyści i naukowcy proweniencji nienazistowskiej? Zadaniem niniejszego tekstu jest próba takiego uzupełnienia stanu badań nad dziejami wzajemnych odniesień nacjonalizmów w Polsce i Niemczech.

Stowa kluczowe: polski nacjonalizm, III Rzesza, nazizm, narodowy socjalizm

D ojście do władzy narodowych socjalistów w Niemczech i budowa totalitarnego systemu III Rzeszy zbiegły się w czasie z postępującą destabilizacją demokracji w Polsce. Lata trzydzieste XX w. były w naszej historii okresem zaostrzania form autorytarnej dyktatury oraz coraz wyraźniejszej radykalizacji polskich środowisk nacjonalistycznych (Wapiński, 1981, s. 183; Rudnicki, 1985, s. 166). Środowiska tzw. „,młodych” obozu narodowego zaczęły rosnąć w siłę płynąc na fali frustracji społecznych i narodowych wywołanych wielkim kryzysem gospodarczym, który boleśnie dotknął także II Rzeczpospolitą. Pozostaje kwestią sporną na ile korzystały one z wzorców nazistowskich (inspiracje faszyzmem włoskim są mniej dyskusyjne) i jak się na ich tle prezentowały. Pisano wówczas wiele w czasopismach firmowanych przez Ruch Młodych Obozu Wielkiej Polski, czy Obóz Narodowo Radykalny o wydarzeniach włoskich i niemieckich, próbowano poszukiwać wzorców, inspiracji i przestróg. Problem relacji między polskim nacjonalizmem a faszyzmem i narodowym 
socjalizmem stał się przedmiotem refleksji naukowej (Kawalec, 1989; Musielak, 1997; Macała, 2000; Marszałek, 2001; Kotowski, 2006). Niestety jak dotąd nie dokonano podobnej analizy, biorąc jako punkt wyjścia Niemcy ówczesnej epoki. Warto zadać pytanie, czy również tam, w publicystyce, w publikacjach naukowych, rozwój polskiego nacjonalizmu wzbudzał zainteresowanie? Jak postrzegali swych polskich ideowych pobratymców zwolennicy ruchu nazistowskiego, jak odnosili się do nich publicyści i naukowcy proweniencji nienazistowskiej? Zadaniem niniejszego tekstu będzie właśnie próba takiego uzupełnienia stanu badań nad dziejami wzajemnych odniesień nacjonalizmów w Polsce i Niemczech.

Ówczesna III Rzesza nie była miejscem stwarzającym sposobność do swobodnej ekspresji poglądów, niewielu potrafiło oprzeć się sile, z którą totalitarny reżim kontrolował ludzkie umysły i działania. Założenie to należy mieć zawsze na względzie jeśli chcemy należycie zinterpretować to co wówczas mówiono i pisano. Pamiętając o tym chciałbym przyjrzeć się opiniom formułowanym w latach trzydziestych wobec polskiego nacjonalizmu w publikacjach nazistowskich oraz w czasopismach i książkach o charakterze naukowym i bardziej popularnym poświęconych problematyce Europy środkowo-wschodniej.

Niemieckie analizy polskiego nacjonalizmu układają się w dość wyraźny schemat, bez względu na to, czy są prezentowane przez nazistowskie koła partyjne, czy też przez naukowców i publicystów podlegających tylko reżimowym ograniczeniom. Dostrzec można kilka problemów, które budziły w Niemczech największe zainteresowanie. Pisze się o polskim obozie narodowym jako głównym twórcy nowoczesnego społeczeństwa i państwa polskiego, szczególnie eksponując aktywność i zasługi jego przywódców w okresie I wojny światowej i konferencji pokojowej w Paryżu. Polska scena polityczna widziana jest jako pole starcia dwu osobowości, za którymi stoją dwie koncepcje kształtu terytorialnego i ustrojowego państwa. Wiele miejsca poświęca się zatem porównaniom postaci Romana Dmowskiego i Józefa Piłsudskiego. Z wieloma reakcjami spotyka się pojawienie się po $1926 \mathrm{r}$. nowej generacji ruchu narodowego w Polsce i jej relacje z faszyzmem włoskim i niemieckim narodowym socjalizmem.

Narodziny na ziemiach polskich w końcowych latach XIX stulecia orientacji nacjonalistycznej były wedle opinii niemieckich aktem emancypacji polskiego mieszczaństwa. Jeden z autorów najczęściej piszących o problemach polskich, jenajski profesor Erich Maschke, ujął to dobitnie: „Dmowski bardziej niż ktokolwiek inny położył duchowe fundamenty 
młodego polskiego mieszczaństwa" (Maschke, 1934/5). Inni autorzy niemieccy właśnie z mieszczańskiego charakteru endecji wywodzili jej antyniemieckość i prorosyjskość. Rosja miała być, wedle ich opinii, daleko mniej groźnym niebezpieczeństwem dla kształtującej się polskiej klasy średniej niż Niemcy, gdzie ta grupa społeczna osiągnęła wysoki stopień rozwoju (Laeuen, 1938/9). Również szczególne zainteresowanie, które wykazywali wszechpolacy wobec kresów zachodnich przypisywano istnieniu tylko tam ukształtowanej polskiej klasy średniej, którą Dmowski czynił wzorcem dla społeczeństwa polskiego w pozostałych dzielnicach (ibidem). Mieszczański charakter endecji widział cytowany już Maschke, jako jedną z przyczyn jej historycznej klęski. Sugerował, iż I wojna światowa zniszczyła tożsamość polskiego mieszczaństwa, pozbawiając je samodzielności politycznej, kulturalnej i duchowej. Została ona zastapiona ideą wyłącznie narodową, co, jak konkludował Maschke, przywódcy nacjonalizmu polskiego dostrzegli zbyt późno (Maschke, 1934/5).

Wiele miejsca poświęcali niemieccy autorzy demokratycznemu charakterowi polskiego ruchu narodowego. Patrząc ze specyficznej perspektywy lat trzydziestych widzieli w nim swego rodzaju grzech pierworodny uniemożliwiający integrację polskiej i niemieckiej formy nacjonalizmu. Ernst Sillinger w volkistowskim „Die Tat” określił Narodową Demokrację jako ruch wyrastający z liberalnej, demokratycznej tradycji dziewiętnastowiecznej Francji, zakorzeniony w ideałach rewolucji 1789 r. Dmowskiego podejrzewał, że w istocie pragnie budować państwo wzorowane na zachodnioeuropejskich demokracjach. Wszelako dostrzegał w endecji również „pierwiastek pruski”, sugerując, iż może to stworzyć trudną do oszacowania szansę na przyszłość. Jego zdaniem dopiero po wykarczowaniu liberalno-demokratycznych korzeni będzie ona mogła stać się czynnikiem odgrywającym w Polsce podobną rolę promotora budowy nowego kształtu Europy tak jak NSDAP w Niemczech (Sillinger, 1933/4). Właśnie ten demoliberalny charakter polskiego nacjonalizmu miał zdaniem autorów niemieckich tłumaczyć sukcesy jego przywódców w działaniach dyplomatycznych związanych z tworzeniem zrębów wersalskiego ładu powojennej Europy. Nikt nie mógł bowiem, domniemywano, bardziej efektywnie reprezentować sprawy polskiej przed trybunałem zwycięskiej Ententy aniżeli wyznawcy tego samego, co wersalski areopag, systemu wartości.

Opinia, że to Dmowski i jego orientacja polityczna stworzyli dyplomatyczny fundament odrodzonej Polski, zdawała się być w Niemczech reprezentowana dość zgodnie przez licznych autorów. Reprezentatywną 
niech będzie w tej kwestii opinia Walthera Recke, autora pracy, która uważana była w Niemczech lat trzydziestych za podstawową dla przedstawienia kwestii polskiej w polityce europejskiej. Wedle jego oceny podczas I wojny światowej na ziemiach polskich endecja dominowała politycznie i wywierała przemożny wpływ na zachowania Polaków. Miał być to argument, z którego pomocą Dmowski inspirował sprzyjające polskiej sprawie działania ówczesnych rządów państw Ententy (Recke, 1927, s. 168-172). Wiara w endecki rząd dusz była wśród niemieckich autorów tak głęboka, iż niektórzy sugerowali nawet, że Rosja nie zaryzykowałaby w 1914 r. wojny z Niemcami, gdyby nie miała przez endecję przygotowanego uprzednio gruntu polskiej lojalności w Kongresówce (Fuchs, 1930, s. 27). Najdobitniej przedstawiła niemieckie przekonanie o podstawowej roli endecji, dla uformowania nowoczesnej polskiej państwowości, Ellinor von Puttkamer. Była ona autorką jedynej w tamtym czasie, samodzielnej, niemieckiej publikacji poświęconej polskiemu ruchowi narodowemu (Dunin Wąsowicz, 1948). Podstawową jej tezą było stwierdzenie, iż: ,polski nacjonalizm stworzył z niczego podstawę, dzięki której stało się możliwe odtworzenie Polski w wojnie światowej” (Puttkamer, 1944, s. 29).

Dominacja inspiracji endeckich w polityce odrodzonego państwa polskiego nie ulegała wątpliwości dla żadnego z autorów niemieckich. Wyrażać się to miało poprzez antyniemiecki charakter polskiego programu terytorialnego ukształtowania granic i całej w zasadzie polityki zagranicznej, która była jakoby oparta na fundamencie kompleksu antyniemieckiego i to bez względu na to, która $\mathrm{z}$ sił politycznych sprawowała w Polsce władzę. Podkreślał to dobitnie Friedrich von Oertzen często pisujący o sprawach wschodnich na łamach nazistowskiego „Volk Und Reich". Wedle jego oceny nawet śmierć Dmowskiego nie spowodowały żadnych istotnych zmian: „bowiem sanacyjne przywództwo doskonale kontynuuje jego naukę" (Oertzen, 1939). Tenże sam autor już wcześniej ostrzegał, że Polacy nie porzucą myśli o opanowaniu Prus Wschodnich, co było częścią terytorialnego programu przywódcy endecji (Oertzen, 1933/34; Schmidt, 1932).

Teza o fikcyjności konfliktu Piłsudskiego i Dmowskiego była często wyrażana w Niemczech lat trzydziestych. Łączono ją z przekonaniem, że także po roku 1926 większość elementów polityki państwa polskiego opartych było na fundamencie narodowo-demokratycznym. Maschke wyraził to najdobitniej pisząc, iż mocarstwowe idee Polski Piłsudskiego wzięte są z ideologii niemieckiej, a: „Dmowski i Piłsudski nie są wroga- 
mi, których cele się wykluczają, lecz ich dzieła uzupełniają się nawzajem" (Maschke, 1938/9).

Zestawieniu tych dwu osobowości poświęcali autorzy niemieccy wiele miejsca. Podkreślano, że w zasadzie nic z tego co działo się ówcześnie w Polsce nie pozostawało poza sporem dwu orientacji reprezentowanych przez tych gigantów polskiej polityki. W niemieckich publikacjach panowała pełna zgodność co do ich dziejowej roli. Piłsudski jest określany jako „Feuerkopf” (ognista głowa), reprezentant powstańczej tradycji polskiego romantyzmu politycznego. Dmowski, to zimny polityk, racjonalista, zawsze gotów stawić czoło zmieniającej się rzeczywistości (Recke, 1927, s. 172). Jeden kontynuował tradycje jagiellońskie, drugi piastowskie (Laeuen, 1938/9). Sugerowano jednak, iż: ,jeśli Marszałek chce zając Kijów musi iść przez Królewiec", trzymano się więc wspomnianej powyżej wizji dominacji koncepcji politycznych Dmowskiego (Ostland, 1932). Piłsudski miał być przedstawicielem epoki schyłkowej, Dmowski lepiej odczytywać ducha czasów współczesnych. Maschke konkludował: „z klęską polityczną połączyło się zwycięstwo świata, który reprezentuje Dmowski" (Maschke, 1938/9).

Ów „współczesny duch” wiał w latach trzydziestych przez Polskę i Niemcy i zmieniał kształt tradycyjnej formy polskiego nacjonalizmu. Jak postrzegali to niemieccy obserwatorzy? Czy ekscesy antysemickie, programy totalizacji życia społecznego i politycznego, zafascynowanie ideą wodzostwa i swoisty „biologizm” polskich młodych narodowców spod znaku ONR - Falangi Bolesława Piaseckiego, były odnotowywane w Niemczech? Czy nazistowscy autorzy dostrzegali podobieństwa polskiej i niemieckiej formy nacjonalizmu? Otóż, co ciekawe, w bardzo ograniczonym stopniu! W końcu lat trzydziestych na łamach czasopisma „Nation und Staat”, które często zajmowało się problematyką narodowościową prezentując ją z nazistowskiego punktu widzenia, Stephan Acker opublikował długi cykl artykułów pod wspólnym tytułem: Der neue Nationalismus (nowy nacjonalizm). Omawiał tam rozmaite, pokrewne hitleryzmowi, ruchy nacjonalistyczne w różnych krajach europejskich, czynił to w sposób niezwykle dokładny, niekiedy wręcz drobiazgowy. Zabrakło jednakże miejsca dla przedstawienia Polski (Weingaertner, 1979, s. 178). Najważniejszy, teoretyczny organ NSDAP: „Nationalsozialistische Monatshefte", nie wspomniał nigdy o polskich narodowcach. Inne programowe czasopismo nazistowskie: „Volk und Reich” raz jedynie, niemalże mimochodem, napomknęło o polskich środowiskach nacjonalistycznych. Ten fenomen słabej recepcji polskiego nacjonalizmu nie wynikał raczej 
z braku zainteresowania Polską. O niemieckiej mniejszości narodowej zapisano dziesiątki stron, Piłsudskiemu i jego obozowi politycznemu poświęcano równie wiele miejsca, sporo pisano o przeszłości ruchu wszechpolskiego i analizowano źródła jego antyniemieckości. Nigdy jednak oficjalna prasa narodowosocjalistyczna nie zajęła się tymi cechami nacjonalizmu polskiego, które mogłyby nasunąć wniosek o jego pokrewieństwie ideowym z hitleryzmem. Fakt ten trudno skomentować w sposób całkowicie jednoznaczny. III Rzesza poszukiwała aż do początku roku 1939 zbliżenia z II Rzeczpospolita, próbowała ją wciagnąć w orbitę swego oddziaływania, dążyła do jej wyłuskania z sojuszu z Francją i wykorzystania w programie nazistowskiej ekspansji na wschód. Przyjazne gesty nazistowskich dostojników kierowane były jednak raczej ku rządzącym Polską środowiskom sanacyjnym. Endecja nie wydawała się im zapewne partnerem możliwym do pozyskania i wartym inwestycji. Decydowała o tym jej głęboka antyniemieckość i być może również niewielkie szanse na zdobycie władzy w Polsce. Jeśli były w okupowanej Polsce osoby, bo raczej nie środowiska, które dopuszczały możliwość znalezienia modus vivendi $\mathrm{z}$ okupantem niemieckim, to rekrutowały się z kręgów konserwatywnych, dalekich od radykalnego nacjonalizmu „młodych” narodowców. Tak było w przypadku Władysława Studnickiego czy Stanisława „Cat” Mackiewicza, których proniemieckość motywowana była nie ideową bliskością z nazizmem, ale swoiście rozumianym politycznym realizmem. Zainteresowanie elit III Rzeszy polskimi narodowymi radykałami, musiałoby uwzględniać jakiś element partnerstwa ideowego, uznania, że Polacy mogą w uzasadniony sposób wyznawać podobne do nazistowskich idee. Nie było na to miejsca ani w poglądach, ani w praktycznych działaniach nazistów.

Hipotezę tę zdaje się potwierdzać fakt, iż inne tytuły, nie aspirujące do miana oficjalnych organów propagandy, choć również naznaczone wpływami nazistowskiej ideologii, poświęcają ewolucji polskiego nacjonalizmu w latach trzydziestych całkiem sporo miejsca.

Dwa motywy powtarzają się w tych analizach ze szczególną intensywnością: porównanie „starej” i „,nowej” formy polskiego nacjonalizmu oraz endecji i sanacji. Cytowany już uprzednio Ernst Sillinger oceniał reżim sanacyjny, szczególnie po śmierci Marszałka, jako pozbawiony głębszej idei, skupiony wyłącznie na utrzymaniu władzy. Właśnie ta bezideowość była, jego zdaniem, przyczyną przejmowania przez obóz władzy haseł ideologii narodowej (Sillinger, 1933/4). Uważał wszelako, iż jest to „upodobnienie bez porozumienia”, czysto powierzchowna kon- 
wergencja. Wyłącznie obóz narodowy miał być siłą posiadającą w Polsce autentyczny i oryginalny wymiar ideowy. Niemieccy autorzy sugerowali jednak, że daleko mu jeszcze do dojrzałości. O. Hoetsch podkreślał, że „stara” Narodowa Demokracja była ciałem obcym wewnątrz społeczeństwa polskiego, ponieważ narodziła się u schyłku dziewiętnastego stulecia na fundamencie zachodnioeuropejskiego liberalizmu i parlamentaryzmu. Idee te miały zostać w sztuczny sposób zaszczepione na ziemiach polskich, których tradycjom historycznym bardziej odpowiadał sanacyjny autorytaryzm. Zamach majowy, „urodzonego na Wschodzie”, Piłsudskiego, który traktował Wschód jako najważniejszy kierunek swej polityki, ukazał jakoby obcość zachodnioeuropejsko zorientowanej endecji na gruncie polskim (Hoetsch, 1932/33). Zastanawiający jest fakt niedostrzegania, bądź lekceważenia $\mathrm{w}$ takich diagnozach tradycji polskiego republikanizmu szlacheckiego I Rzeczpospolitej, jakże przecież wrogiego jakimkolwiek próbom ustanowienia absolutum dominium. Te ahistoryczne w istocie refleksje Hoetscha i Sillingera zdają się świadczyć raczej o dominacji myślenia życzeniowego w ówczesnej niemieckiej publicystyce politycznej aniżeli o poziomie jej historycznej wiedzy.

Po przewrocie majowym zaczęło dochodzić na polskiej scenie politycznej do istotnych przemian, które zmierzały ku konsolidacji i radykalizacji różnych środowisk. Był wśród nich również obóz narodowy. Za sprawą powołania, wzorowanego na włoskim faszyzmie, Obozu Wielkiej Polski doszło do głosu młodsze pokolenie narodowców, które zerwało z demokratycznymi tradycjami twórców polskiego nacjonalizmu. Miejsce dawnych idei zajął kult czynu, hierarchii, swoiście rozumianego porządku oraz coraz bardziej agresywnie formułowany antysemityzm (Rudnicki, 1986, s. 152). Obóz Narodowo Radykalny w rozmaitych swych mutacjach stał się w latach trzydziestych XX stulecia najbardziej wyrazistym przykładem tej tendencji. Jego program wyraźnie, choć nie wprost, nawiązywał do nazistowskich koncepcji budowy państwa i społeczeństwa totalitarnego, w którym całe życie publiczne podporządkowane byłoby jednej organizacji politycznej. Postulowanym modelem ich funkcjonowania miało być tzw. Katolickie Państwo Narodu Polskiego, w którym katolicyzm, wypreparowany z ewangelicznych wartości miłości bliźniego, spełniać miał rolę jedynej ideologii państwowej (Lipski, 2015, s. 90-107).

W niemieckich reakcjach na te przemiany podkreślano ich przełomowy dla polskiej sceny politycznej charakter. W tekście pod znamiennym tytułem: Das junge Polen (młoda Polska) „Osteuropa” stwierdzała, iż 
dotąd istniały na polskiej scenie politycznej dwie, uwarunkowane historycznymi tradycjami, orientacje: pozytywistyczna i romantyczna. Pierwsza z nich kładła nacisk na rozwój duchowej i materialnej substancji narodu, jej spadkobiercą była endecja, druga, propagowała idee irredenty i antyrosyjski kult niepodległości, jej wcieleniem był obóz Piłsudskiego. Polityczny pozytywizm narodowców opierał się na silnym fundamencie intelektualnym i miał zorganizowane zaplecze społeczne, brakowało mu jednak energii i woli zdobycia władzy. Polityczny romantyzm sanacji był zasadniczo bezideowy, to władza była żywiołem, w którym odnajdywał się doskonale. Te same atuty i braki dostrzegano w przywódcach obu obozów. Dmowski, intelektualista, człowiek myśli, sprawdzający się w działaniach dyplomatycznych, ale bez charyzmy i ambicji potrzebnych dla zdobycia i utrzymania władzy. Piłsudski, człowiek czynu, skupiający wokół siebie drużynę wiernych wyznawców, preferujący w polityce działania oparte na improwizacji, bez głębszej podbudowy ideowej. Anonimowy autor „Osteuropy”, konstatował, iż po przełomie 1926 r. zaczęła się w Polsce rodzić nowa, trzecia orientacja polityczna, związana z nową generacją, odrzucającą wzorce przeszłości. Zechce ona zapewne, dowodził, połączyć obie, wcześniejsze polskie tradycje polityczne tworząc na wzór włoskiego faszyzmu i niemieckiego narodowego socjalizmu, masowy, zorganizowany, żądny władzy ruch polityczny i społeczny (,Osteuropa", 1934/5).

Pojawienie się na polskiej scenie politycznej Obozu Narodowo Radykalnego, zdawało się niemieckim obserwatorom praktyczną realizacją wspomnianych powyżej procesów. Właśnie przy tej okazji, po raz pierwszy i ostatni, zabrał głos jeden z oficjalnych organów NSDAP: „Volk und Reich". Zapewne tylko wtedy miarodajny głos partii nazistowskiej, stwierdził istnienie podobieństw sytuacji w Polsce i w Niemczech. Sugerowano, że co prawda większość polskiej młodzieży nie wyzwoliła się jeszcze spod wpływu „mieszczańskiej ideologii” Dmowskiego, ale grupy inspirujące się wzorami niemieckimi i włoskimi wyraźnie rosną w siłę („Volk und Reich”, 1936). Publicysta czasopisma „Ostland”, które zamieszczało przede wszystkim teksty sugerujące potrzebę rewizji kształtu wschodnich granic Niemiec, wyrażał podobną opinię, konstatując, iż program ONR nie jest jeszcze ideowo kompletny i spójny, zdaje się być jedynie „miksturą agitacyjną”. Powtórzona zostaje wielokrotnie wyrażana sugestia, iż jeśli odrzucona zostanie całkowicie: „szkodliwa przeszłość ruchu narodowo demokratycznego", to: ,życie polityczne Polski może jeszcze ukształtować się normalnie" (Ostland, 1934). Normalnie ozna- 
cza tu oczywiście, uformowanie go według ówczesnego niemieckiego wzorca. Inne rewizjonistyczne czasopismo, królewieckie „Osteuropaeische Lageberichte" dowodziło, że pomimo rosnącej siły wpływów idei faszyzmu i narodowego socjalizmu na polską młodzież nie zostały nimi jeszcze objęte „państwowa polityka oświatowa i kulturalna” („Osteuropaeische Lageberichte", 1935).

Swoistym podsumowaniem przedstawionych powyżej refleksji, stał się tekst kilkakrotnie już cytowanego Ericha Maschke opublikowany na łamach konserwatywnego, choć ulegającego wpływom nazistowskim, „Die Tat” (Hecker, 1974, s. 126). Ocenił on, iż nowatorski w polskich warunkach ruch młodych narodowców ma przede wszystkim wymiar społeczny. Postuluje on bowiem połączenie maksymalnego wzmocnienia prerogatyw władzy z pewnym rodzajem narodowego syndykalizmu, a nawet socjalizmu oraz interwencjonizmem państwowym w gospodarce. To jest w istocie narodowy socjalizm, powiada Maschke, dodając że świadomość tego faktu nie jest jeszcze powszechna. Szczególnie „stare” przywództwo endecji zdaje się tego nie dostrzegać lub świadomie od tego uciekać. To młodzi jednak są „w posiadaniu idei przyszłości”. ONR oddzielił się od endeckiego pnia właśnie zainspirowany wzorcami niemieckimi. „To narodowy socjalizm, nie zaś włoski faszyzm był wzorcem dla Jana Mosdorfa”, dobitnie konstatował publicysta „Die Tat” (Maschke, 1934/35).

Trudno nie dostrzec, iż wielu niemieckich autorów skłonnych było patrzeć na ewolucję sytuacji w Polsce z pewną nadzieją, oczekując wszelako większej konsekwencji od swych ideowych pobratymców. Z delikatnym optymizmem oceniano również nacjonalistyczny zwrot w polityce środowisk rządzących w Polsce, który dokonał się po śmierci Piłsudskiego, choć widziano jego źródła przede wszystkim w wymogach politycznej taktyki.

Nie wszystko jednakże w polskim „młodym nacjonalizmie” zdawało się z niemieckiej perspektywy zgodne z ideałem nazistowskim. Dwie kwestie miały być specyficzne dla tegoż nacjonalizmu: wpływ katolicyzmu i kształt antysemityzmu. Obie były trudne do zaakceptowania dla obserwatorów z III Rzeszy. W latach trzydziestych, w II Rzeczpospolitej rosły nastroje antyżydowskie oraz zaostrzał się język i praktyka polityczna środowisk narodowych. Było to widoczne choćby na przykładzie, niezwykle dla społeczności żydowskiej dokuczliwej, akcji bojkotu ekonomicznego oraz ekscesów na wyższych uczelniach wokół haseł „,numerus clausus” i prób wprowadzenia tzw. gett ławkowych. Antysemicki „We- 
ltkampf” opisywał to z nieukrywaną satysfakcją: „widać, że dostrzeżona już w Niemczech prawda rozpoczęła swój marsz także i w Polsce" („Weltkampf”, 1938). Sugerował również, że endecja nie zbuduje swej siły i autorytetu w polskim społeczeństwie bez pogłębienia i rozszerzenia antysemickiego wymiaru swego programu. $\mathrm{W}$ innym miejscu pojawiły się jednak zastrzeżenia. Z odczuwalnym rozczarowaniem autor „Ostlandu" konstatował, że wrogość wobec Żydów jest tylko ,wytrychem” w endeckim dążeniu do władzy. Oceniał ją jako sposób stwarzania przeszkód sanacyjnemu rządowi, który zostawał w ten sposób zepchnięty do defensywy, szczególnie wobec coraz bardziej niechętnego Żydom polskiego społeczeństwa (Ostland, 1936).

Podkreślano społeczny wymiar antysemityzmu endeckiego, odmawiając mu jakiegokolwiek charakteru rasowego. Zarzucano polskim narodowcom, że idzie im tylko o wzmocnienie polskiego charakteru miast i wolnych zawodów. Ostatecznym dowodem braku antysemickiej konsekwencji miał być fakt nieuznawania za Żydów tych, którzy przyjęli chrzest bądź pochodzili z rodzin mieszanych. „Ostland” podsumowywał to w następujący sposób: ,póki to nie zostanie ostatecznie wyjaśnione endecki program żydowski pozostanie teorią” („Ostland”, 1935). Zupełnie zaś kompromitujące miało być dla endeków to, iż zdaniem publicystów niemieckich tolerowali w swoim gronie Żydów i „Judenbastarden”.

Niedostatki polskiej formy antysemityzmu wiązano w Niemczech z katolickim obliczem polskich narodowców. To, iż katolicyzm był czynnikiem decydującym dla uformowania się polskiego nacjonalizmu postrzegano jako swego rodzaju grzech pierworodny. Zupełnie nie do przyjęcia był dla nazistów sojusz narodowej demokracji z Kościołem rzymskokatolickim, który w ich optyce pozostawał kompromitującą formą „klerykalizmu”. Wszystko to uniemożliwiać miało konsekwentne myślenie i działanie w kategoriach rasowych.

Najszerzej diagnozował to zjawisko w przywoływanym już powyżej tekście Erich Maschke. Właśnie znalezienie odpowiedniego szlaku pomiędzy wymogami etycznymi katolicyzmu a narastającym antysemityzmem uznawał on za fundamentalny dylemat polskich młodych narodowców. Stara endecja, według niego, traktowała problem żydowski w sposób wyraźnie oportunistyczny. Dopiero ONR, jako pierwszy, sformułował program antysemicki w sposób jasny, ale nawet on nie pokusił się o jasne zdefiniowanie kto jest a kto nie jest Żydem. Z perspektywy III Rzeszy i uchwalonych podówczas ustaw norymberskich uznawano to za brak konsekwencji będący logicznym następstwem całego rozwoju 
historycznego państwa i narodu polskiego. Miał on się zaczynać z momentem chrystianizacji i być nierozerwalnie powiązany z Kościołem katolickim. Tu widziano zasadniczą i nieusuwalną przeszkodę uniemożliwiająca, pełne utożsamienie polskiej i niemieckiej formy nacjonalizmu. „Czy może ruch podkreślający katolickie zasady państwa i ściśle złączony z Kościołem postulować wprowadzenie nierówności chrześcijan polskiego i żydowskiego pochodzenia?", pytał retorycznie Erich Maschke (Maschke, 1934/35). Zarówno dla niego, jak również dla innych niemieckich autorów, to właśnie katolicyzm był najtrudniejszą do zaakceptowania cechą polskiego nacjonalizmu. Organiczny związek polskości i katolicyzmu widzieli jako powód, dla którego Polacy nigdy nie będą w stanie zbudować swej tożsamości na gruncie biologicznym, rasowym, a zatem nigdy nie staną się, w nazistowskim rozumieniu, „,nowocześni”.

Niemieckie zainteresowanie polskim nacjonalizmem było w latach trzydziestych mniejsze niż można byłoby się spodziewać. Więcej miejsca i uwagi poświęcały mu jedynie czasopisma i wydawnictwa zajmujące się szczególnie problematyką wschodnioeuropejską. To fakt poniekąd zrozumiały i nietrudny do wyttumaczenia. Mimo wszystko zaskakuje jednak, wspominane powyżej, pomijanie tych spraw w oficjalnej prasie nazistowskiej. Sprawy polskie były domeną kilku zaledwie nazwisk: Walthera Recke, Ernsta Sillingera, Friedricha von Oertzena, Harolda Laeuena, Otto Hoetscha i przede wszystkim Ericha Maschke. Publikowali oni na różnych łamach, różnił ich stopień akceptacji ideologii nazistowskiej i poziom używanych argumentów. Żaden jednak nie chciał, a zapewne również nie mógł, przekroczyć granicy, którą wyznaczał totalitarny charakter III Rzeszy, niedopuszczający wolności słowa i myśli.

Można wyróżnić kilka powtarzających się motywów niemieckich analiz polskiego nacjonalizmu. Wyraźnie podkreślana jest jego mieszczańska genealogia, która nadać mu miała geopolityczne oblicze antyniemieckie i prorosyjskie. Dostrzegane są zasługi Narodowej Demokracji podczas I wojny światowej i bezpośrednio po jej zakończeniu. Uformowany wówczas, terytorialny i ustrojowy, kształt polskiej państwowości był, zdaniem niemieckich autorów, efektem jej idei i działań. II Rzeczpospolita postrzegali oni jako pole starcia dwu politycznych orientacji: endeckiej i piłsudczykowskiej oraz dwu politycznych gigantów: Dmowskiego i Piłsudskiego. Po ustanowieniu dyktatury sanacyjnej w $1926 \mathrm{r}$. nie dostrzegano w Polsce właściwie żadnej innej realnej opozycji poza różnymi formacjami obozu narodowego. Ta dychotomia w postrzeganiu polskiej sceny politycznej była jedną z najbardziej konsekwentnych cech 
ówczesnych analiz niemieckich. „Młody” nacjonalizm rozwijający się w latach trzydziestych witany był w Niemczech z satysfakcją, ale akcenty tej oceny rozkładano tam w sposób dość znamienny. Pokrewieństwo z faszyzmem i narodowym socjalizmem podkreślano dość ostrożnie, i nieoficjalnie, niedostatki rasizmu, antysemityzmu i katolickie sentymenty dostrzegano nadzwyczaj często.

Niewiele było w niemieckich opiniach lat trzydziestych oryginalności i głębi przy analizowaniu kształtowania się polskiego obozu narodowego. Jedyny może Erich Maschke, mimo wszelkich ograniczeń, spoglądał na interesujące nas kwestie w sposób nieco mniej skażony nazistowską ideologią i propagandą. Te braki miały swoje konsekwencje w sferze praktycznej polityki. III Rzesza nie próbowała budować powiązań ze środowiskami nacjonalistycznymi w Polsce, preferowała kuszenie rządzącej Polską sanacji. To po śmierci Piłsudskiego, nie Dmowskiego, ogłoszono w Niemczech żałobę narodową. Także po wrześniu 1939 r. nie poszukiwali Niemcy w sposób poważny kontaktów z przedstawicielami polskiego nacjonalizmu. Przeszkadzała w tym zapewne ich antyniemieckość, ale również dalekosiężne, ludobójcze plany reżimu nazistowskiego wobec Polski i Polaków. Wszystkie te kwestie mogą, choć zapewne nie w pełni, tłumaczyć niewielkie zainteresowanie kształtowaniem się polskich środowisk nacjonalistycznych w Niemczech lat trzydziestych.

\section{Bibliografia}

Dunin Wąsowicz K. (1948), Die polnische Nationaldemokratie. Recenzja, „Przegląd Historyczny", nr 37.

Das junge Polen (1934/5), „Osteuropa”, R. 10.

Der neue Polenspiegel. Selbstbezeugnisse polnischen Eroberungswillens (1930), Berlin.

Der Judendietrich der Endeken (1936), „Ostland”, R. 17, nr 7.

„Der Weltkampf” (1938), R. 15, z. 1.

Fuchs W. (1930), Der neue Polenspiegel. Selbstzeugnisse polnischene Eroberungswillens, Deutsche Ostmarkenverein, Berlin.

Hartmann H. (1934), Slawen, Romanen, Germanen als Gestalter europaeischen Schicksals, ,Zeitschrift fuer Politik”, R. 22.

Hecker H. (1974), Die Tat und ihr Osteuropabild 1909-1939, Wissenschaft und Politik, Koeln.

Hoetsch O. (1934), Osteuropa und Deutscher Osten, Ost-Europa-Verlag, Berlin.

Kawalec K. (1989), Narodowa Demokracja wobec faszyzmu 1922-1939, PIW, Warszawa. 
Kotowski A. S. (2006), Narodowa Demokracja wobec nazizmu i Trzeciej Rzeszy, Wydawnictwo Adam Marszałek, Toruń.

Laeuen H. (1938/9), Roman Dmowski, „Jomsborg”, R. 2.

Lipski J. J. (2015), Idea Katolickiego Państwa Narodu Polskiego. Zarys ideologii ONR Falanga, Wydawnictwo Krytyki Politycznej, Warszawa.

Macała J. (2000), Między akceptacjq a odrzuceniem faszystowskich wzorów. Z dyskusji wokót totalizmu katolickiego w polskiej prasie politycznej przed 1939 r., „Studia nad faszyzmem i Zbrodniami Hitlerowskimi”, t. XXIII, Wrocław.

Marszał M. (2001), Włoski faszyzm i niemiecki narodowy socjalizm w pogladach ideologów Narodowej Demokracji 1926-1939, Wydawnictwo Kolonia Limited, Wrocław.

Maschke E. (1933/4), Krise der polnischen Jugend, „Die Tat”, R. 25.

Maschke E. (1934/5), Roman Dmowski, „Osteuropa”, R. 10.

Maschke E. (1938/9), Roman Dmowski 1864-1939, „Osteuropa”, R. 14.

Musielak M. (1997), Nazizm w interpretacjach polskiej myśli politycznej okresu międzywojennego, Wydawnictwo Poznańskie, Poznań.

Oertzen von F. W. (1933), Der Nachbar im Osten, „Zeitschrift fuer Politik”, R. 23.

Oertzen von F. W. (1933/4), Die polnische Gefahr, „Die Tat”, R. 25.

Oertzen von F. W. (1939), Dmowski, ,Volk und Reich”, R. 15.

„Osteuropaeische Lageberichte” (1935), nr 11.

„Osteuropaeische Lageberichte” (1936), nr 19.

„Ostland” (1932), R. 13, nr 17.

„Ostland” (1934), R. 15, nr 16.

„Ostland” (1935), R. 16, nr 16.

Puttkamer von E. (1944), Die polnische Nationaldemokratie, Institut für Deutsche Ostarbeit, Krakau.

Recke W. (1927), Die polnische Frage als Problem der europaeischen Politik, G. Stilke Verlag, Berlin.

Rudnicki S. (1985), Obóz Narodowo Radykalny. Geneza i działalność, Czytelnik, Warszawa.

Schmidt A. (1932), Polen und Ostpreussen, „Zeitschrift fuer Politik”, R. 22.

Sillinger E. (1933/4), Um Polens innere Ordnung, „Die Tat”, R. 25.

„Volk und Reich” (1936), R. 12.

„Volk und Reich” (1939), R. 15.

Wapiński R. (1981), Narodowa Demokracja 1893-1939. Ze studiów nad dziejami myśli nacjonalistycznej, Ossolineum, Wrocław.

Wapiński R. (1988), Roman Dmowski, Wydawnictwo Lubelskie, Lublin.

Weingaertner A. (1979), Nation und Staat. Eine Monographie, Newacademic Press, Wien.

„Zeitschrift fuer Geopolitik” (1934), R. 11. 


\title{
Polish nationalism in the German eyes of the thirties
}

\begin{abstract}
Summary
German interest in Polish nationalism was negligible in the nineteen thirties. Only the magazines and publications dealing with Eastern European issues devoted more time and space to Polish nationalism. They practically ignored the NSDAP sources. The issue of relations between Polish nationalism on the one hand and fascism and national socialism on the other has become the topic of academic research. So far, Germany at that time has never been analyzed in this context. A question worth considering is whether German journalism and academic publications were interested in the development of Polish nationalism. How did the proponents of the Nazi movement perceive their Polish ideological counterparts? What was the attitude of non-Nazi journalists and scholars? The aim of this paper is to try to complement the studies in the history of mutual relations of Polish and German nationalism.
\end{abstract}

Key words: Polish nationalism, the Third Reich, Nazism, National Socialism 